\title{
Pengembagan Perangkat Pembelajaran Team Based Learning- Inquiry Pada Pembelajaran Daring Berbantuan WhatsApp Dan Zoom Meeting Pada Materi Gerak Lurus
}

\author{
Trisnawaty J. Buhungo, Darmansya A. Mustapa*, Asri Arbie \\ Program Studi Pendidikan Fisika, Universitas Negeri Gorontalo \\ *Email: darmansyamustapa@gmail.com
}

Received: 3 November 2021； Accepted: 15 Desember 2021； Published: 19 Desember 2021 DOI: http://dx.doi.org/10.29303/jpft.v7i2.3079

\begin{abstract}
This research was conducted at SMAN 1 Telaga Biru class X MIPA3. The purpose of this study is to produce quality learning tools using the Team Based Learning model to improve student learning outcomes in physics learning. This research uses a modified development model of the ten steps of Borg and Gall's research and development by Sukmadinata and colleagues which consists of three stages, namely preliminary studies, product development, and product testing and dissemination of results. The results showed that: 1) The overall validation of the learning tools was declared valid with a small revision, 2) The practicality of the learning devices was determined through the average percentage of learning implementation in four meetings reaching $97.22 \%$ with very good criteria and teacher and student responses through questionnaires. give a positive response. Based on the results of the study, it can be concluded that the Physics learning device using the Team Based Learning model has met the valid and practical criteria to increase student interest in learning and learning outcomes.
\end{abstract}

Keywords: Learning Tools; Team Based Learning; Inquiry Learning

\section{PENDAHULUAN}

Sesuai dengan surat edaran KemenDikBud Nomor 4 tahun 2020 tentang pelaksanaan kebijakan pendidikan dalam masa darurat penyebaran corona virusdisease (COVID-19), proses belajar mengajar dianjurkan untuk dilaksanakan dari rumah melalui pembelajaran daring. Kesiapan dari pihak penyedia layanan maupun siswa merupakan tuntutan dari pelaksanaan pembelajaran daring. Pelaksanaan pembelajaran daring seperti ini memerlukan perangkat pendukung seperti computer atau laptop, gawai, dan alat bantu lain sebagai perantara yang tentu saja harus terhubung dengan koneksi internet.

Pembelajaran yang dilakukan secara daring dengan menggunakan media atau platform tetunya berdampak pada siswa, guru bahkan sampai orang tua. guru yang kurang mampu beradaptasi dengan kemajuan teknologi tentu saja mengalami kesulitan dan harus menyesuaikan dengan keadaan ini. Selain itu guru juga kesulitan mengakses siswa yang memiliki keterbatasan kuota internet. Dengan adanya hal tersebut, penggunaan media dan bahan ajar yang telah dirancang menjadi kurang maksimal dalam hal pengimplementasiannya.

Pembelajaran yang dilakukan secara daring juga berdampak pada siswa. Dengan diterapkannya pembelajaran daring membuat minat dan hasil belajar peserta didik menurun. Selain itu fokus peserta didik juga ikut berkurang karena tidak melakukan pembelajaran tatap muka secara langsung dan hubungan emosional antara guru dan siswa tidak terbangun. Beranjak dari hal tersebut, orang tua juga ikut merasakan dampak dari pembelajaran daring ini. Orang tua harus menyediakan gawai, kuota untuk mengakses pembelajaran dan bahkan harus menggantikan peran guru dirumah.

Berdasarkan hasil Pengenalan Lapangan Persekolahan (PLP) disekolah, terlihat bahwa pembelajaran yang dilakukan secara daring masih melakukan metode pembelajaran yang berpusat pada guru. 
Dengan menggunakan metode tersebut, peserta didik kurang menerima dan memahami materi yang disampaikan oleh guru. Banyak siswa hanya mendengarkan materi yang disampaikan guru diikuti dengan mematikan kamera dan sibuk dengan urusannya masing-masing. Selain itu, pembelajaran yang dilakukan tanpa eksperimen atau percobaan sederhana membuat siswa kurang memahami konsep materi yang diajarkan. Hal ini menyebabkan kuranggnya pemahaman konsep dan motivasi belajar siswa. Dengan adanya hal ini, pembelajaran harus diubah menjadi pembelajaran yang berpusat pada siswa, baik dari segi pemahaman konsep, media pembelajaran yang digunakan, dan materi pelajaran.

Tentu saja dengan adanya permasalahan ini, guru dituntut untuk lebih kreatif dan inovatif dalam mengembangkan perangkat pembelajaran yang akan digunakan. Perangkat pembelajaran merupakan hal yang perlu dipersiapkan oleh guru sebelum proses pembelajaran berlangsung. Nabila \& Mareta (2017) menyatakan bahwa perangkat pembelajaran adalah sejumlah bahan, alat, media, petunjuk dan pedoman yang akan digunakan dalam dalam proses pembelajaran. Perangkat pembelajaran yang dimaksud dalam penelitian ini adalah perangkat pembelajaran yang dapat membantu guru untuk meningkatkan pemahaman dan motivasi siswa dengan tidak memisahkan antara tubuh dan pikiran. Perlu adanya pengembangan pendektan, model, dan metode yang dapat media yang dapat membantu membangun pemahaman siswa dalam mengikuti proses pembelajaran yang sesuai dengan keadaan saat ini.

Pengembangan perangkat pembelajaran merupakan salah satu cara yang dapat digunakan untuk mengoptimalkan prosess pembelajaran dengan melakukan pemilihan metode, model dan desain yang dapat meningkatkan ketertarikan dan dan motifasi belajar siswa sehingga hal tersebut bisa berdampak besar pada hasil belaajar siswa. Perangat pembelajaran yang diperlukan untuk mengelola proses pembelajaran meliputi silabus, Rencana pelaksanaan pembelajaaraan (RPP), bahan ajar, lembar kegiatan peserta didik (LKPD), instrument evaluasi atau tes hasil belajaar (THB), media pembelajaran serta buku ajar peserta didik (Trianto 2008).

Model pembelajaran yang dapat mengatasi hal ini adalah model pembelajaran Team Base Learning yang dikolaborasikan dengan model pembelajaran Inquiry Learning.

Team Based Learning adalah pembelajaran kelompok kecil yang menerapkan pengetahuan konseptual melalui urutan kegiatan yang termasuk kerja individu, kerja sama team dan umpan balik (Michaelsen et al. 2014). Menurut Dwirahayu (2019) pembelajaran berbasis tim (Team Based Learning) merupakan salah satu pembeljaran yang mendorong siswa secara berkelompok atau saling berinteraksi sosial untuk aktif memecahkan masalah matematika yang diberikan. Pembelajaran Team Based Learning terdapat tiga tahapan pembelajaran yakni Preparation, Readiness Assurance, dan Application Of Course Concept (Rotgans et al. 2019).

Secara garis besar metode inkuiri merupakan metode pembelajaran yang mengkaitkan materi belajar dengan pengalaman siswa. Pengalaman dari masingmasing siswa nantinya akan dirumuskan dan disimpulkan bersama-sama (Fauziyah 2004).

Penggabungan model ini dapat membangun pemahaman dan mampu memecahkan permasalahan dikehidupan nyata apalagi diterapkan selama pembelajaran daring. Pembelajaran inkuiri 
berbasis team merupakan pembelajaran berbasis inkuiri dalam kerangka pembelajaran berbasis tim. Struktur Team Base Inquiry Learning yang kuat dapat menjadikan siswa lebih aktif selama pembelajaran.

\section{METODE PENELITIAN}

Penelitian ini mengacu pada penelitian dan pengembangan yang dimodifikasi dari sepuluh langkah penelitian dan pengembangan dari Borg dan Gall. Hal ini dilakukan karena disesuaikan dengan kebutuhan penelitian tanpa mengurangi substansi prosedur pengembangan produk. Penyesuaian dilakukan untuk mendukung proses pengembangan agar lebih sesuai dengan fokus penelitian. Hasil pengembangan ini difokuskan untuk mengatasi permasalahan-permasalahan pembelajaran. Secara garis besar langkah penelitian dan pengembangan yang dikembangkan oleh Sukmadinata dan kawan-kawan terdiri atas tiga tahap, yaitu: studi pendahuluan, pengembangan produk, dan uji produk dan sosialisasi hasil.

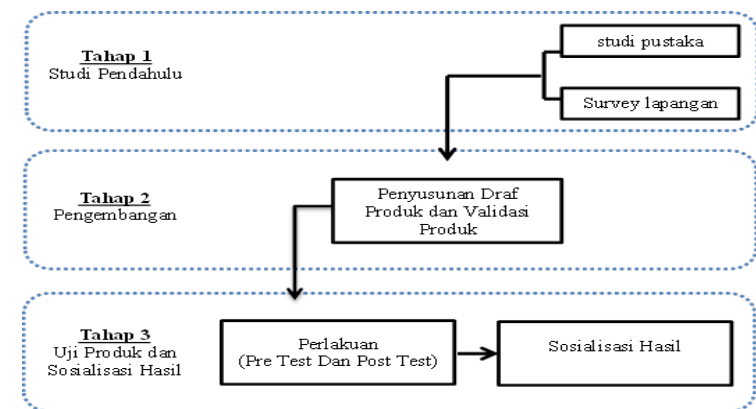

Gambar 1. Metode Pengembangan

Tahap awal dari penelitian ini adalah studi pendahulu yang merupakan tahap pertama untuk persiapan pengembangan. Tahap awal ini terdiri dari tiga langkah, yaitu studi kepustakaan, servei lapangan, dan penyusunan produk awal atau draf perangkat pembelajaran berbasis Team Based Learning.
Tahap selanjutnya yaitu tahap pengembangan produk yang terdiri atas dua langkah yaitu uji coba terbatas dan uji coba lebih luas. Namun dalam penelitian ini tidak dilakukan uji coba lebih luas melainkan hanya uji coba terbatas saja. Hal ini dikarenakan penelitin yang dilakukan hanya di salah satu sekolah di kabupaten Gorontalo yang menerapkan pembelajaran daring.

Uji coba dilakukan dalam rangka mengetahui kualitas produk.Validasi melalui uji lapangan dilakukan dengan disain kuasi eksperimen yang dilakukan pada skala terbatas dengan menggunakan produk awal dan pada situasi sesungguhnya dalam pembelajaran dengan menggunakan produk ujicoba.Data empiris pada ujicoba produk awal merupakan informasi untuk refleksi dan revisi produk, yang kemudian menghasilkan produk ujicoba yang siap digunakan dalam pembelajaran yang sesungguhnya. Data hasil penelitian produk ujicoba merupakan informasi untuk refleksi dan revisi produk, yang kemudian menghasilkan produk akhir. Tahap ini merupakan uji empiris yang dilakukan untuk menguji validitas produk melalui angket dengan menggunakan analisis deskriptif untuk mengetahui kelayakan produk bahan ajar. Dalam penelitian ini, penelitilah yang bertugas sebagai guru yang melakukan kegiatan pembelajaran sebanyak 4 kali pertemuan pada materi Gerak Luruss. Penelitian ini dilakukan oleh 3 orang pengamat, yang mana masing-masing pengamat keterlaksanaan pembelajaran, pengamatan aktivitas siswa, pengamatan sikap siswa, serta pengamat penilaian keterampilan siswa.

\section{HASIL DAN PEMBAHASAN}

Pada penelitian ini berhasil menghasilakn perangkan pembelajaran yang berkualitas yang meliputi tiga aspek yaitu valid, praktis dan efektif. 
Hasil

a. Validitas

Validitas perangkat pembelajaran diketahui melalui komentar dan saran para ahli pada lembar validasi. Perangkat pembelajaraan yang akan digunnakan harus divalidasi oleh para ahli atau validator untuk mengetahui valid atau tidak perangkat pembelajaran tersebut untuk digunakan. Perangkat pembelajaran yang digunakan divalidasi oleh 3 orang validator dengan perangkat yang divalidasi adalah Silabus, RPP, LKPD, dan Bahan Ajar.

Tabel 2. Hasil Validasi Perangkat Pembelajaran

\begin{tabular}{ccccc}
\hline & \multicolumn{4}{c}{ Persentase } \\
\cline { 2 - 5 } Validator & Silabus & RPP & $\begin{array}{c}\text { Bahan } \\
\text { Ajar }\end{array}$ & LKPD \\
& 100 & 79 & 79 & 79 \\
I & 92.5 & 77 & 76 & 77 \\
II & 100 & 77 & 76 & 78 \\
\hline III & 97.5 & 77.67 & 77 & 78
\end{tabular}

Berdasarkan Tabel 2 di atas, perangkat pembelajaran yang dikembangkan dinyatakan valid dengan rata-rata hasil validasi untuk silabus memperoleh persentase $97.5 \%$, untuk RPP, rata-rata persentase yang diperoleh adalah $77,67 \%$. Bahan ajar dinyatakan valid dengan raa-rata persentase dari validator sebesar $77 \%$ dan untuk LKPD memperoleh persentase $78 \%$.

\section{b. Kepraktisan}

Kepraktisan pembelajaran dapat dilihat dari keterlaksanaan pembelejaran yang sesuai dengan langkah-langkah yang terdapat pada RPP serta dapat dilihat juga melalui respon guru.

Tabel 3. Keterlaksanaan Pembelajaran

\begin{tabular}{ccc}
\hline Pertemuan & $\begin{array}{c}\text { Peresentase } \\
\text { Keterlaksanaan }(\%)\end{array}$ & Kriteria \\
\hline 1 & 96,29 & Sangat Baik \\
2 & 100 & Sangat Baik \\
3 & 92,59 & Sangat Baik \\
\hline
\end{tabular}

\begin{tabular}{ccc}
\hline Pertemuan & $\begin{array}{c}\text { Peresentase } \\
\text { Keterlaksanaan }(\%)\end{array}$ & Kriteria \\
\hline 4 & 100 & Sangat Baik \\
\hline Rata-Rata & 97,22 & Sangat Baik \\
\hline
\end{tabular}

Tabel diatas menunjukan persentase dari keterlaksanaan pembelajaran untuk 4 pertemuan mencapai kriteria sangat baik.

Kepraktisan perangkat pembelajaran juga dilihat dari angket respon peserta didik dan guru. Respon guru dan peserta didik dapat dilihat pada tabel 4 dan tabel 5 .

Tabel 4. Persentase Respon Peserta Didik

\begin{tabular}{ccc}
\hline Indikator & $\begin{array}{c}\text { Persentase Respon Peserta } \\
\text { Didik }(\%)\end{array}$ & Kriteria \\
\hline 1 & 79.13 & Baik \\
2 & 80.52 & Baik \\
3 & 80.63 & Baik \\
4 & 80.73 & Baik \\
5 & 77.5 & Baik \\
6 & 81.04 & Baik \\
7 & 81.5 & Baik \\
\hline Rata-rata & 80.15 & Baik \\
\hline \multicolumn{2}{c}{ Berdasarkan tabel diatas, } & dapat
\end{tabular}

dilihat bahwa hasil angket respon peserta didik untuk keseluruhan indikator yaitu sebesar $80,15 \%$ dan termasuk dalam kategori baik.

Tabel 5. Persentase Respon Guru

\begin{tabular}{ccc}
\hline Indikator & $\begin{array}{c}\text { Persentase Respon Peserta } \\
\text { Didik (\%) }\end{array}$ & Kriteria \\
\hline 1 & 80 & Baik \\
2 & 80 & Baik \\
3 & 80 & Baik \\
4 & 80 & Baik \\
5 & 80 & Baik \\
6 & 80 & Baik \\
\hline Rata-rata & 80 & Baik \\
\hline
\end{tabular}

Berdasarkan tabel diatas, dapat dilihat bahwa hasil angket respon guru untuk keseluruhan indikator yaitu sebesar $80 \%$ dan termasuk dalam kategori baik. 


\section{Pembahasan}

Valid tidaknya perangkat pembelajaran yang akan digunakan ditentukan melalui pendapat professional melalui telaah instrument per item perangkat maupun secara keseluruhan perangkat yang dikembangkan. Aspek yang dinilai ahli yaitu konstruksi, isi, keterbacaan, bahasa, daan penampilan untuk setiap instrument perangkat pembelajaraan. Hasil telaah dari paara ahli dijadikan masukan dan bahan revisi perangkat pembelajaran. Validitas perangkat pembelajaran yang dikembangkan mencakup silabus, rencana pelaksanaan pembelajaran (RPP), bahan ajar, lembar kerja peserta didik (LKPD) dan instrument penilaian kompetensi. Berdasarkan validasi yang telah dilakukan, perangkat pembelajaran dapat digunakan dengan revisi kecil dan masuk dalam kriteria valid.

Kepraktisan perangkat pembelajaran dapat ditinjau dari: (1) keterlaksanaan pembelajaran; (2) angket respon guru dan peserta didik. Berdasarkan hasil pengamatan yang dilakukan oleh pengamat terhadap pembelajaran oleh guru bahwa keterlaksanaan pembelajaran sesuai dengan langkah-langkah yang dituliskan di RPP untuk pertemuan pertama berada pada presentase $96,29 \%$, pada pertemuan kedua $100 \%$, pertemuan ketiga $92,59 \%$, serta pertemuan keempat $100 \%$ sehingga rata-rata dari presentase keterlaksanaan pembelajaran berada pada $97.22 \%$ hal ini memperoleh predikat sangat baik dan praktis untuk diterapkan dalam proses pembelajaran. Seperti halnya penelitian yang telah dilakukan oleh Wahyuni, Kosim, dan Gunawan (2018) yang menyatakan bahwa keterlaksanaan pembelajaran berada pada kategori sangat praktis dan terbukti efektif untuk meningkatkan penguasaan konsep siswa.

Respon guru mengenai perangkat pembelajaran yang telah dikembangkan (silabus, RPP, LKPD, bahan ajar, instrumen penilaian kompetensi sikap, pengetahuan dan keterampilan) secara keseluruhan mendapatkan respon positif dengan masingmasing komponen perangkat dikategorikan "sangat baik" berdasarkan kriteria menurut (Purnomo 2014:92). Sejalan dengan penelitian yang dilakuka oleh Sahidu et al. (2018) yang menyatakan bahwa perangkat yang dikembangkan berada pada kategori baik, dapat digunakan untuk mendukung pembelajaran fisika.

Respon guru dan peserta didik mengenai proses pembelajaran dilihat dari beberapa indikator dan mendapatkan respon positif. Berdasarkan hasil angke respon guru persentase yang didapatkan adalah $80 \%$ (baik) sedangkan respon peserta didik memperoleh rata-rata $80,15 \%$ (baik) dengan penjelasan bahwa kegiatan pembelajaran yang berbasis tim dapat menumbuhkan semangat peserta didik pada proses pembelajaran. Jika dibandingkan dengan pembelajaran sebelumnya maka pembelajaran menggunakan model Team Based Learning (TBL) dapat membuat peserta didik lebih aktif karena peserta didik terlibat langsung dalam melakukan kegiatan pembelajaran. Dari respon positif yang diperoleh melalui angket menunjukkan bahwa perangkat pembelajaran yang telah dikembangkan dikatakan praktis dalam implementasinya di dalam kelas.

\section{PENUTUP}

Berdasarkan hasil penelitian dan pembahasan dapat disimpulkan bahwa perangkat pembelajaran Fisika yang dikembangkan menggunakan model Team Based Learning (TBL) pada materi Gerak Lurus di kelas X SMAN 1 Telaga Biru telah memenuhi kriteria berkualitas yang meliputi tiga aspek yaitu valid, praktis dan efektif.

Perangkat pembelajaran yang dikembangkan telah memenuhi kriteria valid yang diperoleh dari hasil validasi oleh validator yang didasarkan pada beberapa aspek (kontruksi, isi, keterbacaan dan 
bahasa). Dengan menggunakan lembar validasi yang terdiri dari lembar validasi tiap item dan keseluruhan. Komentar tersebut menyatakan bahwa perangkat pembelajaran yang dikembangkan layak digunakan atau valid dengan revisi kecil.

$$
\text { Perangkat pembelajaran yang }
$$
dikembangkan telah memenuhi kriteria praktis karena keterlaksanaan pembelajaran yang dilakukan guru mencapai 97,22\% dengan kategori sangat baik, dan setelah diberikan angket respon guru dan peserta didik terhadap pembelajaran yang menggunakan model Team Based Learning (TBL) diperoleh respon yang positif sehingga dapat disimpulkan bahwa perangkat ini praktis/mudah untuk dilaksanakan dalam proses pembelajaran.

Berdasarkan uraian diatas disarankan perlu diadakan penelitian lebih lanjut dalam skala yang lebih luas tentang hasil pengembangan perangkat pembelajaran ini, baik pada penggunaan model pembelajaran maupun model pengembangan perangkat sehingga dapat meningkatkan motivasi peserta didik dalam belajar fisika.

\section{REFERENSI}

Dwirahayu, G. (2019). "Penerapan Team Based Learning ( TBL ) untuk Meningkatkan Pemahaman Konsep pada Materi Statstik." (November 2018).

Fauziyah, D. (2004). "Penerapan Strategi Pembelajaran Inquiry Pada Mata Pelajaran Ekonomi Pokok Bahasan Pasar." : 49-59.

KemenDikBud. (2020). "Pelaksanaan Kebijakan Pendidikan Dalam Masa Darurat Penyebaran Coronavirus Disease (COVID-19)."

Michaelsen, Larry K, Neil Davidson, \& Claire Howell Major. (2014). “TeamBased Learning Practices and Principles in Comparison With Cooperative Learning and Problem-
Based Learning." Journal on Excellence in College Teaching 25: 57-84.

Nabila, L. A., \& Nila M. 2017. "Pengembangan Perangkat

Pembelajaran Berbasis Pendekatan Kontekstual pada Materi Bangun Datar Berorientasi pada Pemahaman Konsep Siswa Kelas VII SMP.” Jurnal Pendidikan Matematika 6(7): 58-72. http://journal.student.uny.ac.id/ojs/ind ex.php/pmath/article/view/7887\%0A.

Purnomo, B. (2014). Pengembangan Bahan Ajar Ilmu Pengetahuan Sosial Terpadu Dengan Pendekatan Kontekstual Pada SMP Kelas IX Semester I Budi Purnomo 1." Jurnal ilmiah Universitas Batanghari 14(2): 89-96.

Rotgans, Jerome I, Preman Rajalingam, Michael A Ferenczi, dan Naomi Lowbeer. (2019). "A Students ' Model of Team-based Learning." Health Professions Education 5(4): 294-302. http://dx.doi.org/10.1016/j.hpe.2018.1 0.003 .

Sahidu, H, G Gunawan, Rokhmat, J. \& Rahayu, S. (2018). "Pengembangan Perangkat Pembelajaran Fisika Berorientasi Pada Kreativitas Calon Guru." Jurnal Pendidikan Fisika dan Teknologi 4(1): 1.

Trianto. (2008). Mendesain Pembelajaran Kontekstual. Jakarta: Cerdas Pustaka.

Wahyuni, S, K Kosim, \& G Gunawan. (2018). "Pengembangan Perangkat Pembelajaran Fisika Berbasis Inkuiri Terbimbing Berbantuan Eksperimen Untuk Meningkatkan Penguasaan Konsep Siswa." Jurnal Pendidikan Fisika dan Teknologi 4(2): 240. 